Research Paper No. 2005/19

\title{
Voluntary Contributions to Informal Activities Producing Public Goods: Can these be Induced by Government and other Formal Sector Agents?
}

\author{
Some Evidence from Indonesian Posyandus
}

Jeffrey B. Nugent ${ }^{1}$ and Shailender Swaminathan ${ }^{2}$

April 2005

\begin{abstract}
This study attempts to determine the extent to which human potential may be unlocked by government or other formal sector actions that induce voluntary contributions by individuals to the activities of Indonesia's posyandus or village health posts. Posyandus have been an important feature of Indonesia's public health system and have contributed substantially to the country's success in lowering infant and child mortality rates at low cost.

Our analysis of links between formal activity and voluntary contributions to posyandus is conducted at two levels: individuals and posyandus, and with two different indicators at each level. Our empirical results take advantage of data from all three waves of the Indonesian Family Life Survey (IFLS), i.e., IFLS1, IFLS2 and IFLS3. At each level of analysis there is evidence that voluntary contributions and effective service provision can be positively affected by formal sector intervention. Both community level characteristics, such as income per capita, income inequality, ethnic and religious diversity, and household and individual characteristics have different effects on the different outcome variables at both levels of analysis. The results demonstrate that appropriately designed formal sector interventions can induce voluntary inputs and, through the public goods produced, they can unlock the human potential.
\end{abstract}

Keywords: voluntarism, Indonesia, health service provision, government intervention

JEL classification: H42, I18, J22, O15, O17, R29

Copyright (C) EGDI and UNU-WIDER 2005

${ }^{1}$ University of Southern California, USA; ${ }^{2}$ University of Alabama, USA

This study was presented at the EGDI-WIDER Conference on Unlocking Human Potential - Linking the Informal and Formal Sectors in Helsinki, 17-18 September 2004.

UNU-WIDER gratefully acknowledges the support and collaboration of the Expert Group on Development Issues (EGDI) of the Swedish Ministry of Foreign Affairs. UNU-WIDER also acknowledges the financial contributions to its research programme by the governments of Denmark (Royal Ministry of Foreign Affairs), Finland (Ministry for Foreign Affairs), Norway (Royal Ministry of Foreign Affairs), Sweden (Swedish International Development Cooperation Agency - Sida) and the United Kingdom (Department for International Development). 


\section{Acknowledgements}

The authors express their appreciation to Tomoya Matsumoto for his valuable programming assistance. We also thank seminar participants at the EGDI-WIDER Conference in Helsinki, and especially to Elinor Ostrom, Amos Sawyer and Lyn Squire for detailed comments and useful discussion.

Tables and figures appear at the end of the paper.

The World Institute for Development Economics Research (WIDER) was established by the United Nations University (UNU) as its first research and training centre and started work in Helsinki, Finland in 1985. The Institute undertakes applied research and policy analysis on structural changes affecting the developing and transitional economies, provides a forum for the advocacy of policies leading to robust, equitable and environmentally sustainable growth, and promotes capacity strengthening and training in the field of economic and social policy making. Work is carried out by staff researchers and visiting scholars in Helsinki and through networks of collaborating scholars and institutions around the world.

www.wider.unu.edu

publications@wider.unu.edu

UNU World Institute for Development Economics Research (UNU-WIDER)

Katajanokanlaituri 6 B, 00160 Helsinki, Finland

Camera-ready typescript prepared by Janis Vehmaan-Kreula at UNU-WIDER

The views expressed in this publication are those of the author(s). Publication does not imply endorsement by the Institute or the United Nations University, nor by the programme/project sponsors, of any of the views expressed. 


\section{Introduction}

The purpose of this study is to determine the extent to which human potential may be unlocked by government or other formal sector contributions that serve to induce informal sector and voluntary contributions by individuals in such a way as to produce important local public goods. The nature of the study is motivated by the extreme scarcity of funding by government and external donors at present and in the foreseeable future in developing countries and the dearth of private providers of local public goods and services or even markets for such services. Given the rather dismal prospects for formal sector provision of local public goods, the informal sector is a potentially important vehicle for unlocking the human potential by producing appropriate kinds of public goods, especially health and education services.

One important set of informal sector activities are those involving voluntary activities, such as time and money volunteered to various kinds of informal community associations. These associations are typically not 'owned' in any formal sense but only in a very loose sense by the collective membership of these associations. Often, the voluntary contributions of time, in-kind goods and services and money to these institutions by community members are the most important source of public goods production at the local level. This is especially so in developing countries where private markets for the various public goods are underdeveloped and where, because of their limited local tax base, local governments are extremely resource-constrained.

Yet, both casual observation and the studies reported in the growing literature on local public goods production make it clear that the number and quality of activities provided by the same type of informal institution may vary considerably across countries and communities according to various community characteristics, such as its size, level of development, degree of income inequality, ethnic and religious diversity. Even more importantly, the magnitude and character of government or other formal sector participation in these associations, such as the government's contribution of funds to their start-up, maintenance, management or choice of activities, may vary from one association to another both within and between communities.

To accomplish the objective of this paper, we attempt to identify (1) the magnitude and direction of the effects of external interventions as well as those of various community, household and individual characteristics on the voluntary contributions of individuals to informal activities of the 'unlocking human potential' type, and (2) how the effective provision of human potential unlocking activities at the level of the local service provider is affected by different forms of external support and supervision as well as by a variety of community level characteristics.

Such an analysis is used to help answer questions such as the following: (1) How do different forms of formal and external contributions affect the effective supply of voluntary activities and affect service provisions at the service provider level? (2) Do government contributions 'crowd in' or 'crowd out' voluntary contributions? (3) In what way and to what extent do these answers differ across different types of voluntary contributions? (4) To what extent and how are these effects modified by community level characteristics such as per capita income, the level of income inequality, and ethnic and religious diversity at the community level? (5) How do the characteristics of the individual (age, education, marital status) or of the household (income, household size) influence these voluntary outcomes? 
Quite naturally, the answers to these questions have important policy implications. The benefits of private sector activities and the provision of government-supplied infrastructure and services for the well-being of different segments of the community will depend very considerably on the nature of the relationships identified above. If the provision of goods, services and employment by the formal sector merely substitutes for those provided by informal institutions, the net benefits may be much smaller than in the case in which the activities are in fact complementary. The knowledge of the character of these relationships and how they are affected by community and other characteristics may go a long way toward designing optimal mechanisms for 'unlocking the human potential' through these linkages.

The study also provides implications for theory, especially that of behavioural economics, since voluntary contributions may well constitute 'selfless' or 'altruistic' behaviour, an important subject of investigation in both behavioural economics (Dawes and Thaler 1988, Mullainathan and Thaler 2000 and Rabin 1998) and Public Choice Theory. It also has very considerable relevance to the theory of local public goods.

The paper is organized as follows: Section 2 which follows provides a brief review of relevant literature on local public goods production and the role of informal activities. Section 3 defends the choice of both country (Indonesia) and informal service providers (posyandus) and describes the data set. Section 4 describes the methods. Section 5 presents the empirical results. Section 6 derives implications for theory, policy and further research.

\section{Brief review of relevant literature}

The importance of local public goods as a means of facilitating investments in human capital and the establishment of firms is generally appreciated. Indeed, many of the basic needs of human beings and especially the basic services to develop human capabilities are supplied in the form of public goods at the local level (Sen 1985). Basic education, health, protection of person and property, the supply and maintenance of water supply, local streets and other infrastructure are in most countries supplied by the public or NGO sector at the local level.

There is a large and growing literature on public goods in general and local public goods in particular. Basic contributions are those of Olson (1965) and Hardin (1968; 1982). Although many of these local public goods are not pure public goods, and hence not fully jointly consumable and use non-excludable, they typically share these characteristics to some degree. This implies that their provision is inhibited by the incentive to 'free-ride'. This of course undermines the efforts that local communities may make in providing the local public goods. Indeed, it is widely, though not universally, believed that, as a result, public goods production will be too low.

Much of the literature has been devoted to identifying various characteristics of groups that may be advantageous in helping to overcome the free rider problem and hence the bias toward undersupply of public goods. Olson (1965) and Hardin (1982) for example argued that small size groups may be more successful than large ones, groups in which its members have been closely associated for long periods of time and/or share common backgrounds more successful than others, etc. The effects of some of these group 
characteristics, however, are controversial. For example, Olson (1965) argued that income or wealth inequality might stimulate collective action whereas others like Bardhan (2000) have argued that it would weaken collective action. Similarly, some feel that ethnic or religious diversity would help the production of local public goods whereas others believe the opposite.

To the extent that exclusion of non-contributors is possible, the incentive to free-ride may be weakened. Public goods in such situation are called 'club goods' and the underproduction problem controlled. Another tool for overcoming the incentive for free-riding is the practice of selective incentives, compensating people for their voluntary contributions in some way, perhaps with non-monetary rewards, or by assigning penalties to those who do not contribute. The extent to which people are desirous or in need of the public good can also be a factor. Those who would especially benefit from the public good for example would have greater incentive to contribute than others. Finally, if the group can be organized for some other purpose, for example in a democratic country by a 'political entrepreneur', this could greatly mitigate the problem.

Because the effects of income inequality and ethnic and religious diversity have been especially controversial, much research has been devoted to these effects in recent years. Evidence provided by Alberto Alesina and various co-authors, especially Alesina et al. (1999) and Easterly and Levine (1997), show that some countries and regions within countries are considerably disadvantaged in the production of local public goods by virtue of considerable ethnic diversity. Strong evidence of the deleterious effects of income inequality on public goods production at the local level is provided for Indonesia by Swaminathan and Nugent (2003) and Nugent and Swaminathan (2004). This effect may be realized in several ways: (1) by making it more difficult to agree on the kind and quality of public goods to be produced and how to finance them, (2) by diverting expenditures away from development-related public goods toward incentivereducing redistributive transfers (Alesina and Perotti 1996; Persson and Tabellini 1992, 1994). Since redistributive spending tends to be low in developing countries, mechanism (1) would seem more plausible. But even in this case, the exact reasons and underlying mechanisms are unclear. For example, is it the fact that the heterogeneous members have different tastes such that a compromise public good provides less satisfaction to all? Or is it that members of different groups within the community are altruistic within groups but not across groups? Or could it be that there is less public safety in more heterogeneous communities, making community members afraid to participate in community activities outside the home. Or could it be that it is less possible to impose sanctions (to mitigate the free-riding incentive) on those not contributing to the voluntary public good activities when these community members are from a different ethnic, religious or income group (Miguel and Gugerty 2002)? Even if answers to these questions can be obtained, how can these problems arising from heterogeneity be overcome (e.g., by forcibly relocating community members into homogeneous ones, by stressing integration into the national community, or by decentralizing institutions and their activities to the level of the income or ethnic group within the community?

On the other hand, as indicated above, collective action theory can also lead us to believe that greater income inequality or ethnic diversity can have positive (rather than negative) effects on the supply of local public goods. 
Another relevant literature for the determinants of voluntary activities and public goods production is that of behavioural economics. Thus far, most research in this field has been concentrated on developed countries. The fact that substantial percentages of the population in such countries have been engaged in voluntary activities has been taken to constitute prima facie evidence in support of the hypothesis of behavioural economics that behaviour is only boundedly selfish instead of purely selfish (Mullainathan and Thaler 2000). Yet, even so, time spent in such activities can be explained by considerations such as (1) tax laws discriminating against labour supply of secondary workers in the household ('the marriage tax'), (2) the direct consumption utility derived from participatory community activities, and (3) the future potential commercial usefulness of the contacts developed in such work. Considerations (2) and (3) are especially plausible given that the rich and famous are often well-represented in such activities. Moreover, if one assumes that the utility of money income diminishes quite sharply at high levels, it may be very difficult to distinguish between purely and boundedly selfish behaviours.

But, even in such a context, the existing literature alerts us to the fact that self-interest may be relevant in another form. For example, a woman may be more likely to volunteer time to the local school the more children of her own she has in the school or to the local health center the more that she anticipates the need of herself and her family members to use that facility. How much of observed volunteer activities can be attributed to these family self interest motives? How much to the relative importance of friends and acquaintances of the same ethnic or income group in the community among the users of such services for whom the volunteers may have some altruistic preferences?

To what extent does visibility of participation make for greater participation in volunteering to community services and to what extent does the volunteering by some depend on the identities of others seen volunteering? Dawes and Thaler (1988), Rabin (1998) and other behavioural economists have suggested that people are more likely to volunteer when they see others with whom they share some 'reciprocal altruism' also volunteer. By comparing volunteerism and the patterns of such across members of the community in small villages with those in towns and cities we should be able to measure the importance of visibility. Since experimental evidence has often shown the importance of pre-game communication to cooperative outcomes such as the production of public goods, we also hope to distinguish the effect of actual selfless behaviour from the effect of communication on the likelihood and extent of mutual participation in voluntary community activities.

Other factors that might explain voluntarism and in the process distinguish between bounded self-interest and reciprocal altruism are conditions in labour markets and income levels. If individuals were primarily motivated by the desire to earn income with voluntary labour supplies to the public service activities mainly derived as a residual, then we would expect a substitution effect between labour supply in the market and labour supply in voluntary activities. As a result, a higher market wage would result in greater time spent on market activities and less time spent on voluntary activities. On the other hand, if individuals set target income levels, as shown by Camerer et al. (1997), then a higher market wage might result in a higher labour supply to voluntary activities. 
Yet another emerging theme in the behavioural economics literature is that 'context effects' are important (Camerer and Loewenstein 2003). Thus individuals would behave differently in contexts where spending time in voluntary public good activities is an option to market work than in contexts where voluntary labour supply is not an option.

\section{Choice of country, Posyandus and the Indonesian data set}

Indonesia is chosen as the country of study for several reasons, including its relatively low level of development, its economic and cultural diversity, and the diversity of its informal sector activities. To accomplish the aforementioned objectives and to answer the important questions posed above, very detailed data at the individual, household and community levels on formal and informal sector activities as well as on the numerous factors that have to be controlled for are required. Fortunately, such data is available and the study takes advantage of the three waves (one only recently released) of the Indonesian Family Life Survey (IFLS 1, 2 and 3). Table 1 presents a description of the variables and variable names used in the analysis.

One important feature of IFLS is the detailed information provided by the individual and household questionnaires concerning the time and money contributed voluntarily to each informal and formal sector activity by each of 19,800 individuals sampled from the 321 communities. In each community, information was collected from a sample of health facilities - both formal and informal. Taken together also, the various questionnaires provide the information that can be used to control for community size, income inequality, ethnic diversity, employment opportunities, the level of development and government-supplied infrastructure. Another strength of the data is the extremely low rates of attrition of households from the initial sample in the subsequent rounds of the survey.

For the informal sector whose determinants of voluntary activities are studied we choose 'posyandus' or impermanent integrated community health posts. The posyandus' primarily provide health services to young children and family planning services to adults. These community health posts have been shown to have played a very important role in Indonesia's public health strategy and in the substantial success that Indonesia has enjoyed in lowering its infant mortality rate and more generally raising the country's health statistics and human development index. Posyandus typically operate in a community only about once a month and, while staffed by volunteers, can benefit from supervision and visits from trained staff (including physicians and midwives) from the government-run health centers (puskesmas) and family planning clinics. Financial support for posyandus comes from several sources including the village budget and local community members. In addition, a large part of the instruments and supplies used in the posyandus (such as weighing scales, vitamin pills) is provided by the health centers. The services provided by posyandus are based almost entirely on volunteers or very minimally remunerated cadres and make use of extremely low cost but effective instruments and materials. Organized at the community level by the Family Welfare Movement (PKK), Indonesia's posyandus have won awards from both the World Health Organization and UNICEF for their success in volunteerism and health improvement.

By the mid-1980s posyandus became a critical feature of Indonesia's overall development and health improvement plans and, as a result, their presence spread 
rapidly. From 20,000 in 1985, the number of posyandus increased to about 200,000 in 1988 and became available in almost every village by the early 1990s. Especially given their voluntary character and the 1997-98 financial crisis, however, posyandus have had their ups and downs. Indeed, during the crisis the activity levels and quality of posyandu volunteerism and services deteriorated substantially. Table 3 shows that the proportion of women who participated in posyandus fell from 22 per cent in 1997 to 15 per cent in 2000. It also shows some decline in the average number of cadres in posyandus over the 1993 to 2000 period. Notably, there is also a sizable variance around the mean in any given year and it is this variability over time as well as over space that makes the posyandu experience over the three waves of IFLS, i.e., between 1993 and 2000, so useful for a study such as ours. The deterioration in the quality of the posyandus' was sufficiently great in 1997-98 that in 1998 a Posyandu Revitalization Programme was initiated, but only in certain communities. Table 2 shows that about 50 per cent of the posyandus in 2000 were part of the revitalization programme. This revitalization comprised cadre training, improving the incentives of the cadres, and improving the quality of the instruments in the posyandus. Rather clear distinctions can be made between inputs supplied by government and other formal sector organizations (as in the Posyandu Revitalization Programme or some other means of external supply of funds, staff, supervision or material and equipment supply) and those contributed on a voluntary basis by individuals.

In particular, for both 1993 and 1997 there is information at the level of the posyandu about inputs from both formal and informal sectors. For example, among the former are the frequency of the supervision of the posyandu by the formal health center (puskesmas). At the same time, for each posyandu, there is information on the quantity, quality and frequency of the services provided and the number of users. Finally, from the sampled adult women, there is information on both their participation and hours volunteered to the posyandus and the quality of services received by their children when visiting the posyandus.

Table 5 presents descriptive statistics for the main independent variables used in the analysis. However, the statistics in Table 5 mask the degree of change over time within a given community. To take a closer look at these variations we present Figures 1A, 1B, and $1 \mathrm{C}$. From the means presented in Table 5, it appears as if the number of posyandus in a community has not shown much variation over time. Figure $1 \mathrm{C}$, however, dispels that notion. While some communities did not exhibit change (those along the 45-degree line) in the number of posyandus, there are quite a few that experienced either increases or decreases between 1997 and 2000. Similar variation is observed for two other 'formal' interventions: the average number of instruments in the posyandu, and the number of visits per year from the family planning clinic to the posyandu. The dependent variables exhibit variation as well. While at the individual level participation in the posyandu has declined over time, at the posyandu level, the number of visitors has increased over time. This seems to suggest that while the extent of volunteerism shows a slight decline, the extent of utilization of the posyandu (possibly reflecting nonvoluntary behaviour) has increased over time. 


\section{Methods}

The goal in this paper is to estimate the effect of formal interventions on participation in, and the quality of, involuntary institutions. To achieve this goal, we estimate models at two different levels: At the posyandu level, we estimate the determinants of two outcomes: (i) the number of cadres, and (ii) the number of visitors. At the individual level, we estimate the determinants of another two outcomes: (iii) participation of individual women in the posyandu as users of posyandu services, and (iv) the quality of the posyandu as measured by the care individual children received. The formal intervention variables used include supervision of posyandu activities by the staff of the puskesmas, funding of the posyandu from the village budget, the posyandu revitalization programme, and other variables such as education, income, and income inequality. The description of covariates used in the models is presented in Table 1.

For outcomes (i), (ii) and (iii) above, we estimate two specifications that vary in the way the effect of formal intervention is identified. The general specification can be written as:

$$
y_{j t}=\beta_{0}+\beta_{1} \text { Interven }_{j t}+\beta_{2} X_{j t}+\delta_{j}+v_{j t}
$$

In this model $(j)$ indexes observation (either individual or posyandu), and $(t)$ indexes time. The first specification is the random effects model that uses cross-sectional and longitudinal variation in Interven ${ }_{j t}$ to identify $\beta_{2}$. The second specification is the fixed effects model that uses only variation in Interven $_{j t}$ over time to identify the model. The advantage of the fixed effects model is that it eliminates any bias caused by correlation between Interven ${ }_{j t}$ and $\delta_{j}$. This correlation might exist, for example, if formal interventions are more likely in areas where individuals have a lower propensity to participate in community activities. When the unit of observation is the posyandu, we cannot introduce fixed effects at the posyandu level but do so at the community level. This is because posyandus are, by their very nature informal institutions, and hence cannot be linked over time. Introducing community level fixed effects in the posyandu level model allows us to identify $\beta_{2}$ using both longitudinal and cross-sectional variation in Interven ${ }_{j t}$ among posyandus' within a community.

Our final model (iv) estimates the effect of formal intervention on the quality of healthcare provided to a child visiting the posyandu. Since comparable data is not available in the earlier waves of IFLS, to estimate this model we use data only from Wave 3 (2000). This model provides an estimate of the effect of formal intervention on the probability of receiving specific kinds of healthcare in the posyandu, namely, vitamin A pills, an immunization, and an oral rehydration solution for treating diarrhea.

The model estimated here is:

$$
q_{i j}=\gamma_{1 j} \text { Interven }_{i}+\gamma_{2 j} X_{i}+u_{i j}
$$

where $q_{i j}$ indicates whether service of type $(j)$ has been provided to child (i), Interven is the formal intervention, and $X$ are other controls. The problem in unbiased estimation of equation (2) is that $q$ is not observed for children that have not visited the posyandu in 
the four weeks prior to the survey. If those children that have visited the posyandu are a non-random subset of the entire sample of children, the estimates in equation (1) might be biased. To account for this potential non-random selection, we also jointly estimate the selection equation:

$q_{i, \text { not missing }}=\alpha_{1} Z_{i}+\alpha_{2} X_{i}+v_{i}$

The correlation in the error terms in equations (2) and (2') is identified using the instruments in the vector $Z_{i}$ that includes variables such as the number of posyandus' in the community, household income, etc. Table 1 lists the covariates used in both the service (2) and selection (2') equations. For each type of service, equations (2) and (2') are estimated by maximum likelihood allowing for correlation in the error terms $u$ and $v$.

\section{Empirical results}

The results for volunteerism at the individual level are presented in Table 4. We estimate models for two different measures of posyandu participation, namely the decision to participate or not (DmPART) and the number of hours devoted to posyandu activities (HOURS). Since the former is a binary variable, it is estimated by Probit. Since the latter is continuous but bounded below at zero, it is estimated by Tobit.

Table 3 presents the results for both DmPART and HOURS. The asterisks next to the parameter estimates reflect the level of significance $(*, * *$, and $* * *$ reflecting levels of 10, 5 and 1 per cent, respectively). Beginning with the characteristics of the individual woman, schooling has positive effects on both variables of voluntary activity in posyandus. Age has a non-linear effect (positive up to a point but then declining); being married and having children less than five years of age have very significant positive effects on both. At the household level, income per capita has negative and significant effects, and speaking the same language as the majority in the community has a positive but not significant effect (except in the case of fixed effects in which case the effect on dmPART is negative and significant at the 10 per cent level). At the community level, both language diversity and average per capita income have negative and significant effects on both measures of participation in posyandus. As to the intervention variables, the average number of instruments in each posyandu (TINST), the number of annual visits from staff of the National Family Planning Board (FPLANV) and the number of posyandus in the community all have positive and significant effects on both dmPART and HOURS. Urban location, visits of puskesmas staff to the posyandus and the total number of activities in the community have no significant influences on either measure of voluntary participation in posyundu activities.

The strength of the age and other demographic effects shows that voluntary participation by Indonesian women in the informal posyandu sector is very much a life cycle phenomenon, and very much triggered by marriage and having small children. This can also be interpreted as relative need for the services that posyandus provide, suggesting that such volunteerism is by no means selfless in nature. The fact that both household and community level per capita income have negative effects on posyandu participation is indicative that the institution of posyandus is one that caters primarily to poor people. It might also imply that individuals' with better labour market prospects 
(and hence higher household income) are less inclined to participate in the voluntary activity. The positive effect of inequality in per capita income can be interpreted in a similar way since, for any given per capita income at the community level, greater inequality would imply a relatively larger proportion of poor people in the community. As suggested in the local public goods literature, ethnic diversity (reflected in language) has a negative influence on participation in voluntary activities for posyandus.

As far as the effect of formal sector activities on participation, there are several pieces of evidence that these effects are positive. Education is a formal sector activity that has positive and significant effects on both measures of participation. Likewise, the following measures of formal sector contribution to and supervision of posyandu activities: AVGTINST, AVGFPVIS and NUMBPOS, all have positive and significant effects on voluntary activities by individuals to posyandus. To provide a better sense of the magnitude of these effects we simulated the effect of a change in specified covariates when value of the other covariates was fixed at their means. Doing so, we find that increasing the number of visits of staff from the family planning clinic from once every four months to once every month will increase the probability of participating in the posyandu by about 2 percentage points. Relative to the mean participation probability of about 0.18 , this represents a slightly higher than 10 per cent increase. Further, increasing the education level of women from a primary (six years) to junior high (10 years) increases the probability of participation by 2 percentage points.

Next, we turn to the results at the posyandu level given in Table 5. In this case, we use the number of cadres in a posyandu (CADRES) as a measure of volunteerism and then the total number of visits to posyandus (VISITS) during the last three months as a measure of client participation, reflecting in part the quality of services offered by the posyandu. The CADRES measure is clearly more closely related to the volunteer participation at the individual level in Table 4 than is VISITS. Similar to the results at the individual level, schooling and the inequality of per capita income both have positive and significant effects on CADRES. By the same token, YPC has a negative effect (though in this case it is not statistically different from zero). Of special interest, however, are the positive and significant effects of the posyandu getting funds from the village budget and the number of instruments that the posyandu has (TINST). Since these are clearly both measures of perceived formal sector support to posyandu activities, these results suggest once again that volunteer activities can be induced by formal sector contributions. Note also that these effects are just as strong in the fixed effects estimates as in the random effects ones. The number of instruments in the posyandu is a significant determinant of the number of cadres. Simulation results show that starting with covariate values at their respective means, increasing the number of instruments in the posyandu from 3 to 6 increases the number of cadres by about 10 per cent.

From the results for VISITS given in the last two columns of the table, one can again see the positive effect of instruments (TINST). Having a posyandu revitalization programme (POSYREVIT) also has a positive and significant influence. VISITS is presumably a measure that reflects the quality and deemed usefulness of posyandu services. Note that in this case YPC at the community level has a significant positive effect and the inequality in YPC a highly significant negative effect. The latter finding is consistent with our aforementioned earlier results (also for Indonesia and based on the same data sets) showing that inequality was found to have a significant negative effect on health care utilization and educational investments at the individual level. Average 
schooling levels in this case have a negative and significant effect, possibly reflecting the fact that those communities with more education on average would be expected to have more formal sector sources of health service provision than would those with lower schooling levels. Simulation results reveal that increasing the posyandu's number of instruments from 3 to 6 increases the number of visitors by about 10 per cent while posyandus with revitalization had on average about 140 more visitors than posyandus without revitalization.

While VISITS may be a reasonable proxy for quality of posyandu service provision on the grounds that if the community members did not find the services valuable they would not make the visits, it is certainly a rather blunt measure. Clearly, the connection to service quality and health outcomes is at best only suggestive. In the final step of our analysis we go on treat the visit to a posyandu (VISITPOS) as a selection equation (to test for the possibility of selection bias) and then attempt to explain variations in the delivery of each of the three specific services mentioned above - labelled VITAMIN, IMMUN and ORALR, respectively - to these individuals. Once again, we introduce controls for various individual, household and community characteristics but place special emphasis on the effects of formal sector contributions. The formal sector interventions examined are: (a) the presence at the time of delivery of the service of a staff member from the (formal sector) 'puskesmas' or public health clinic (PUSKSTAFF), (b) whether or not the posyandu received any funding from the village budget (VILFUND), and (c) whether or not the posyandu had a Posyandu Revitalization Programme (POSYREVIT). Since both the VISITPOS and each of the three service provision variables are $(0,1)$ dummy variables, in each case the parameters of the jointly estimated selection and service equations are probit estimates. The results are presented in Table 6.

Turning first to the results for VITAMIN, we find that both VILFUND and POSYREVIT have positive effects on the probability that vitamin pills are provided when a child visits the posyandu. Of even greater relevance is the positive and significant coefficient of PUSKSTAFF in the probit equation for VITAMIN. The selection equation (VISITPOS) results reveal no evidence of gender bias (CHILDMALE) but a very strong negative influence of CHILDAGE, positive effects of the number of posyandus in the community (NUMPOS) (a measure of proximity) and the income inequality measure GINIYPC. The fact that household income has a negative effect further supports our explanation for our interpretation that the posyandu is an informal sector institution primarily serving the poor. We cannot reject the null hypothesis that the correlation in the error terms in the service and selection equations is zero.

The second set of results in the table is that for ORALR. Quite naturally, the results for the selection equation (VISITPOS) are virtually identical to those found in the selection equation for VITAMIN. Once again, the effect on the formal sector contribution measure PUSKSTAFF is positive and significant at the 1 per cent level. None of the other determinants have statistically significant influences on ORALR. There is also evidence that those more likely to visit the posyandu are also more likely to receive Oral Rehydration Solution (correlation between $u$ and $v$ is positive).

Finally, we discuss the results for immunization (IMMUN). Once again, we find that having health center staff present at the time of the posyandu visit increases the likelihood of the child getting immunized. Not surprisingly, older children are less 
likely to be immunized when they visit the posyandu. None of the other formal sector variables affect the probability of immunization. The presence of a staff member from the puskesmas (health center) is significantly associated with provision of all three services. We simulate the effect of a presence of a staff member on the probability of service provision conditional on the child visiting the posyandu. We find that the conditional probability of the child receiving vitamin pills increases from 0.72 to 0.79 when the staff member is present. Similarly, we find that the conditional probability of receiving ORS increases from 0.13 to 0.37 when a staff member is present. Finally, the conditional probability of getting immunized increases from 0.03 to 0.08 when the staff member is present.

\section{Conclusions}

What kinds of implications can be drawn from this analysis for both theory and policy? First, from the descriptive statistics we saw there has been considerable voluntary participation in informal activity by Indonesian women even though there has been a decline over the period 1997-2000. To a large extent, posyandu participation and hours of time provided are dictated by life cycle and demographic factors. Those who are married with young children are much more likely to participate than other women (younger and older without young children). This would suggest that much of the voluntarism in local public goods production is partly motivated by self interest in that the women who participate are those most likely to need the services provided by posyandus. Since use is negatively related to income both at the household and community levels and positively related to income inequality at the community level, we interpret this as an indication that the primary beneficiaries and those most in need of these services are relatively poor people who cannot easily afford other alternatives.

Since the services produced by the posyandus are quasi-public goods, our results also have implications for the theory of collective action in general and local public goods in particular. Of particular relevance are the effects of income inequality and ethnic or religious diversity. Ethnic diversity was shown to have a negative effect on voluntary participation in posyandus while at the same time the individual speaking the same language at home as the majority in the village has a positive but not significant effect. On the other hand, per capita income inequality exerts negative effects only in the case of quality-related measures of posyandu activities as reflected in the number of visitors to the posyandu. Inequality, on the other hand is positively related with participation in informal activities. This finding, though a bit surprising, is perhaps because income inequality is picking up elements of community level poverty since a higher gini coefficient might also imply more poor people in the community. It might also be that income inequality is very imprecisely measured. Substantial components of income, especially those from self-employment are not reported in the data. Future work will consider other options such as merging in district level inequality measures constructed using data from National Household Surveys (SUSENAS).

Finally, given our focus on the relevance of formal sector contributions and support for informal sector activity, the most important findings are the positive effects of several of the indicators of formal sector support for posyandus. The validity of our estimates is bolstered by the fact that in both random and fixed effects specifications, several formal interventions are significantly related to volunteer participation and service provision in 
the posyandu. The fixed effects results allow us to generate more 'causal' conclusions. An increase in the number of instruments at the posyandu or the number of visits from staff from the family planning clinic increases the probability that a woman will participate in the posyandu. Similarly, increasing the education levels also leads to higher participation. At the posyandu level, 140 more visits were observed to those posyandus that underwent a revitalization programme in 1998-1999 compared to those posyandus' that did not. Taken as a whole, these results suggest a significant role for the formal sector in inducing participation in posyandu activities, and improving the quality of services provided by such informal institutions based largely on voluntary participation.

\section{References}

Alesina, A., R. Baqir and W. Easterly (1999). 'Public Goods and Ethnic Divisions'. Quarterly Journal of Economics, 114 (4), 1243-84.

Alesina, A. and R. Perotti (1996). 'Income Distribution, Political Instability and Growth’. European Economic Review, 40, 1203-28.

Bardhan, P. (2000). 'Understanding Underdevelopment: Challenges for Institutional Economics from the Point of View of Poor Countries'. Journal of Institutional Economics (JITE) 156, 216-35.

Camerer, C., L. Babcock, G. Loewenstein and R. Thaler (1997). 'Labor Supply of New York City Cabdrivers: One Day at a Time’. Quarterly Journal of Economics, 112 (2), 407-41.

Camerer, C. and G. Loewenstein (2003). 'Behavioral Economics: Past, Present, Future', in C. Camerer, G. Loewenstein and M. Rabin (eds), Advances in Behavioral Economics. Princeton, NJ: Princeton University Press.

Dawes, R. M. and R. H. Thaler (1988). ‘Anomalies: Cooperation’. Journal of Economic Perspectives, 8 (4), 45-64.

Easterly, W. and R. Levine (1997). 'Africa’s Growth Tragedy: Policies and Ethnic Divisions', Quarterly Journal of Economics; 112 (4), 1203-50.

Hardin, G. (1968). 'The Tragedy of the Commons'. Science 162 (December), 1243-48.

Hardin, R. (1982). Collective Action. Washington, DC: Resources for the Future.

Miguel, E. and M. K. Gugerty (2002). 'Ethnic Diversity, Social Sanctions and Public Goods in Kenya’, Berkeley: University of California Working Paper.

Mullainathan and Thaler (2000). 'Behavioral Economics', NBER Working Paper 7948. Cambridge, MA: NBER.

Nugent, J. and S. Swaminathan (2004). 'Household Investments in Education and Income Inequality at the Community Level: Evidence from Indonesia', in A. de Janvry and R. Kanbur (eds), Poverty, Inequality and Development: Essays in Honor of Erik Thorbecke, Cornell University, Boston: Kluwer.

Olson, M. (1965). The Logic of Collective Action: Public Goods and the Theory of Groups. Cambridge, MA: Harvard University Press. 
Persson, T. and G. Tabellini (1992). 'Growth, Distribution and Politics', in A. Cuckierman, Z. Hercowitz and L. Lederman (eds), Political Economy, Growth and Business Cycles. Cambridge, MA: MIT Press.

Persson, T. and G. Tabellini (1994). 'Is Inequality Harmful for Growth?', American Economic Review, 84(3): 600-21.

Rabin, M. (1998). 'Psychology and Economics', Journal of Economic Literature 36 (March), 11-46.

Sen, A. K. (1985). Commodities and Capabilities. Amsterdam: North-Holland.

Swaminathan, S. and J. Nugent (2003). 'Income Inequality and Investments in Prenatal Care: Evidence from Indonesia’. Under review. 
Table 1

Model specifications

\begin{tabular}{|c|c|c|c|c|c|}
\hline Variables & $\begin{array}{l}\text { Participation/ } \\
\text { hours in } \\
\text { Posyandu }\end{array}$ & $\begin{array}{l}\text { \# Cadres in } \\
\text { Posyandu }\end{array}$ & $\begin{array}{c}\text { \# Visitors } \\
\text { to } \\
\text { Posyandu }\end{array}$ & $\begin{array}{l}\text { Posyandu } \\
\text { services to } \\
\text { children }\end{array}$ & $\begin{array}{l}\text { Child visit } \\
\text { to } \\
\text { Posyandu }\end{array}$ \\
\hline $\begin{array}{l}\text { YRSSCHOOL (Education level of women in } \\
\text { years) }\end{array}$ & $x$ & & & & $x$ \\
\hline AGE (age of woman) & $x$ & & & & $x$ \\
\hline AGE squared & $x$ & & & & $x$ \\
\hline Gini of YPC (community level gini of income) & $x$ & & & $x$ & $\mathrm{x}$ \\
\hline DmMARRIED (married dummy) & $x$ & & & & $x$ \\
\hline KIDS0-5 (\# kids between 0-5 years) & $x$ & & & & $x$ \\
\hline URBAN (urban dummy) & $x$ & $x$ & $x$ & & $x$ \\
\hline DIVLANG (diversity in language ) & $x$ & $\mathrm{x}$ & $x$ & & $x$ \\
\hline $\begin{array}{l}\text { dmMJRLNG (dummy: own language is } \\
\text { majority) }\end{array}$ & $x$ & & & & $x$ \\
\hline YPC (total household income) & $x$ & $x$ & $x$ & & $x$ \\
\hline CmYPC (mean community income) & $\mathrm{x}$ & $\mathrm{x}$ & $\mathrm{x}$ & $\mathrm{x}$ & $\mathrm{x}$ \\
\hline CmPOP (population in community- in 1997) & & $x$ & $x$ & & \\
\hline $\begin{array}{l}\text { CmYRSSCHOOL (avg. educ. level in } \\
\text { community) }\end{array}$ & & $x$ & $x$ & & \\
\hline $\begin{array}{l}\text { AVGTINST (avg. no. of instruments per } \\
\text { posyandu) }\end{array}$ & $x$ & & & & $x$ \\
\hline $\begin{array}{l}\text { AVGPUSKV (avg. no. of annual puskesmas } \\
\text { visits) }\end{array}$ & $x$ & & & & $x$ \\
\hline $\begin{array}{l}\text { AVGFPVIS (avg. no. of annual family planning } \\
\text { visits) }\end{array}$ & $x$ & & & & $x$ \\
\hline NUMBPOS (no. of Posyandus in community) & $x$ & & & & $x$ \\
\hline $\begin{array}{l}\text { NUMBPUSK (no. of Puskesmas in } \\
\text { community) }\end{array}$ & $x$ & & & & $x$ \\
\hline $\begin{array}{l}\text { PUSKFUND (Posyandu funding from } \\
\text { Puskesmas) }\end{array}$ & & $x$ & $x$ & & \\
\hline $\begin{array}{l}\text { VILBUD (Posyandu funding from village } \\
\text { budget) }\end{array}$ & & $x$ & $x$ & & \\
\hline TINST (no. of instruments in Posyandu) & & $x$ & $x$ & & \\
\hline POSYREVIT (Posyandu revitalization) & & $x$ & $x$ & & \\
\hline $\begin{array}{l}\text { PUSKSTAFF(staff from Puskesmas when } \\
\text { child visit) }\end{array}$ & & & & $x$ & \\
\hline CHILDAGE (age of child) & & & & $\mathrm{x}$ & \\
\hline $\begin{array}{l}\text { FRAC_VILBUD (fraction of Posyandus } \\
\text { funding from village budget) }\end{array}$ & & & & $x$ & \\
\hline $\begin{array}{l}\text { FRAC_POSREVIT (fraction of Posyandus } \\
\text { revitalized) }\end{array}$ & & & & $\mathrm{x}$ & \\
\hline
\end{tabular}

Note: $x$ 's indicate that the variable was used in the model while blanks indicate the variable was not used. 
Table 2

Longitudinal and cross-sectional variation in important covariates and dependent variables

\begin{tabular}{lccc}
\hline & 1993 & 1997 & 2000 \\
\hline Community level & & & \\
FRAC_VILBUD & 0.35 & 0.39 & 0.31 \\
AVGFPVIS & 1.39 & 7.78 & 5.81 \\
& $(0.85)$ & $(3.89)$ & $(3.92)$ \\
AVGTINST & 7.25 & 7.47 & 5.56 \\
& $(1.5)$ & $(2.06)$ & $(2.00)$ \\
NUMBPOS & 8.67 & 8.35 & 8.30 \\
Gini of YPC & $(8.19)$ & $(6.64)$ & $(6.78)$ \\
& 0.70 & 0.5 & 0.5 \\
DIVLANG & $(0.11)$ & $(0.09)$ & $(0.09)$ \\
Posyandu Level & $x$ & 0.18 & 0.19 \\
VILBUD & & $(0.22)$ & $(0.23)$ \\
TINST & & & \\
POSREVIT & 0.35 & 0.38 & 0.31 \\
PUSKSTAFF & 7.2 & 7.5 & 5.5 \\
Other covariates used in analysis & $(2.1)$ & $(2.6)$ & $(2.6)$ \\
YRSSCHOOL & 0 & 0 & 0.48 \\
AGE & $x$ & $x$ & 0.81 \\
DmMARRIED & & & \\
KIDSO-5 & & & 6.28 \\
URBAN & & & $(4.35)$ \\
CHILDAGE & & & 37 \\
CHILDMALE & & & $(16)$ \\
YPC & & & 0.64 \\
CmYPC & & & 1.29 \\
& & & $0.56)$ \\
& & & $(4.36)$ \\
& & & 0.50 \\
& & & 1172762 \\
& & & 1189486 \\
& & & $(659605)$ \\
\hline
\end{tabular}

Notes:

(1) x's in the table represents non-availability for that variable-year combination.

(2) Standard deviations in parenthesis for continuous variables, but are not reported for discrete variables. 
Table 3

Variation in the dependent variables

\begin{tabular}{|c|c|c|c|c|c|}
\hline Dependent variables & 1993 & 1997 & 2000 & Model & Estimation \\
\hline $\begin{array}{l}\text { Participation in } \\
\text { posyandu by women }\end{array}$ & $x$ & 0.22 & 0.15 & $\begin{array}{l}\text { Logit: random } \\
\text { and } \\
\text { conditional } \\
\text { fixed effects }\end{array}$ & $\begin{array}{l}\text { Maximum } \\
\text { likelihood }\end{array}$ \\
\hline $\begin{array}{l}\text { Annual hours involved } \\
\text { in posyandu activities }\end{array}$ & $x$ & $\begin{array}{l}14.3 \\
(16.6)\end{array}$ & $\begin{array}{l}14.8 \\
(17.1)\end{array}$ & $\begin{array}{l}\text { Tobit model: } \\
\text { random } \\
\text { effects }\end{array}$ & $\begin{array}{l}\text { Generalized } \\
\text { least squares }\end{array}$ \\
\hline Number of cadres & $\begin{array}{l}5.5 \\
(3.3)\end{array}$ & $\begin{array}{c}4.4 \\
(2.6)\end{array}$ & $\begin{array}{l}4.8 \\
(2.4)\end{array}$ & $\begin{array}{l}\text { Poisson: } \\
\text { random and } \\
\text { fixed effects }\end{array}$ & $\begin{array}{l}\text { Maximum } \\
\text { likelihood }\end{array}$ \\
\hline $\begin{array}{l}\text { Total number of } \\
\text { visitors in three } \\
\text { months prior to survey }\end{array}$ & $\begin{array}{l}102.6 \\
(50.9)\end{array}$ & $\begin{array}{l}152.4 \\
(122.9)\end{array}$ & $\begin{array}{c}303.1 \\
(236.1)\end{array}$ & $\begin{array}{l}\text { Linear model: } \\
\text { random and } \\
\text { fixed effects }\end{array}$ & $\begin{array}{l}\text { Generalized } \\
\text { least squares }\end{array}$ \\
\hline $\begin{array}{l}\text { Child received service } \\
\text { at posyandu: vitamin A } \\
\text { pill }\end{array}$ & $x$ & $x$ & 0.55 & $\begin{array}{l}\text { Probit model } \\
\text { estimated } \\
\text { jointly with } \\
\text { selection into } \\
\text { posyandu visit }\end{array}$ & $\begin{array}{l}\text { Maximum } \\
\text { likelihood }\end{array}$ \\
\hline $\begin{array}{l}\text { Child received service } \\
\text { at posyandu: oral } \\
\text { rehydration solution }\end{array}$ & $x$ & $x$ & 0.12 & $\begin{array}{l}\text { Probit model } \\
\text { estimated } \\
\text { jointly with } \\
\text { selection into } \\
\text { posyandu visit }\end{array}$ & $\begin{array}{l}\text { Maximum } \\
\text { likelihood }\end{array}$ \\
\hline $\begin{array}{l}\text { Child received service } \\
\text { at posyandu: } \\
\text { Immunization }\end{array}$ & $x$ & $x$ & 0.48 & $\begin{array}{l}\text { Probit model } \\
\text { estimated } \\
\text { jointly with } \\
\text { selection into } \\
\text { posyandu visit }\end{array}$ & $\begin{array}{l}\text { Maximum } \\
\text { likelihood }\end{array}$ \\
\hline $\begin{array}{l}\text { Child visited posyandu } \\
\text { in four weeks prior to } \\
\text { survey }\end{array}$ & $x$ & $x$ & 0.13 & $\begin{array}{l}\text { Selection } \\
\text { equation }\end{array}$ & $\begin{array}{l}\text { Maximum } \\
\text { likelihood }\end{array}$ \\
\hline
\end{tabular}


Table 4

Participation in and hours supplied to Posyandu by women

\begin{tabular}{|c|c|c|c|}
\hline \multirow[t]{2}{*}{ Explanatory variable } & \multicolumn{2}{|c|}{ Participation (DmPART) } & \multirow{2}{*}{$\frac{\text { Hours }}{\text { Random effects }}$} \\
\hline & Random effects & Fixed effects & \\
\hline YRSSCHOOL & $0.0620^{* \star *}$ & $0.1551^{* \star *}$ & $0.8039 * * *$ \\
\hline AGE & $0.0657^{\star \star \star}$ & $0.1354^{* * *}$ & $0.6171^{* \star *}$ \\
\hline AGE squared & $-0.0018^{\star \star *}$ & $-0.0025^{\star \star \star}$ & $-0.0173^{\star \star \star}$ \\
\hline Gini of YPC & 0.3283 & $0.8420^{*}$ & $6.1452^{*}$ \\
\hline DmMARRIED & $2.0998^{\star \star \star}$ & $1.9158^{\star \star \star}$ & $23.799^{\star \star \star}$ \\
\hline KIDSO-5 & $0.7840^{\star \star \star}$ & $0.3453^{\star *}$ & $8.2226^{\star \star \star}$ \\
\hline URBAN & -0.0304 & - & -0.4073 \\
\hline DIVLANG & $-0.5044^{\star \star \star}$ & -0.4491 & $-4.5829 \star \star$ \\
\hline dmMJRLNG & 0.0730 & $-0.2861^{*}$ & 1.5829 \\
\hline YPC & $-0.0001^{\star \star \star}$ & $-0.0001^{\star \star}$ & $-0.0010 * \star \star$ \\
\hline CmYPC & $-0.0005^{\star \star \star}$ & $-0.0006^{\star \star \star}$ & $-0.0047^{\star \star \star}$ \\
\hline AVGTINST & $0.0199 *$ & $0.0358^{\star}$ & $0.2581^{\star}$ \\
\hline AVGPUSKV & 0.0052 & 0.0057 & 0.0237 \\
\hline AVGFPVIS & $0.0199^{* \star *}$ & $0.0222^{\star *}$ & 0.1077 \\
\hline NUMBPOS & $0.0314^{* * *}$ & $0.0542^{*}$ & $0.3762^{\star \star *}$ \\
\hline NUMBPUSK & 0.0003 & 0.0032 & -0.0859 \\
\hline CONSTANT & 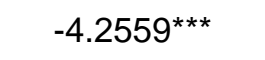 & - & $-54.5386^{\star \star \star}$ \\
\hline Log likelihood & -6780 & -1771 & -19611 \\
\hline
\end{tabular}

Note: ${ }^{* \star *},{ }^{* *}$, and * indicate that the coefficient indicated is statistically significant at the 1,5 and 10 per cent levels, respectively. 
Table 5

Posyandu level participation by volunteers (cadres) and clients

\begin{tabular}{|c|c|c|c|c|}
\hline \multirow{2}{*}{ Explanatory variable } & \multicolumn{2}{|c|}{ Number of cadres in Posyandu } & \multicolumn{2}{|c|}{$\begin{array}{l}\text { Total number of visits to Posyandu } \\
\text { during last three months }\end{array}$} \\
\hline & $\begin{array}{l}\text { Random } \\
\text { effects }\end{array}$ & Fixed effects & $\begin{array}{l}\text { Random } \\
\text { effects }\end{array}$ & Fixed effects \\
\hline Health center funding & 0.0235 & 0.0365 & 7.3773 & 2.1995 \\
\hline Village budget funding & $0.0472^{*}$ & $0.0661^{\star \star}$ & -8.5307 & -0.9272 \\
\hline TINST & $0.0188^{\star \star \star}$ & $0.0151^{\star \star *}$ & $4.774^{\star \star \star}$ & $3.5060^{\star *}$ \\
\hline POSYREVIT & 0.0200 & 0.0193 & $140.1894^{\star \star \star}$ & $143.9775^{\star \star \star}$ \\
\hline GiniYPC & $0.5514^{\star \star \star}$ & $0.6200^{\star \star \star}$ & $-277.1782^{\star \star \star}$ & $-320.3041^{\star \star \star}$ \\
\hline $\begin{array}{l}\text { CmYPC (in millions of } \\
\text { rupiah) }\end{array}$ & -0.003 & -0.0054 & $0.0045^{\star \star \star}$ & $0.0059^{\star \star \star}$ \\
\hline CmYRSSCHOOL & $0.0289 \star \star \star$ & -0.0239 & $-4.8472^{\star \star}$ & $-21.7575^{\star \star \star}$ \\
\hline CmPOP & $0.0044^{\star \star \star}$ & - & $0.0013^{\star * \star}$ & - \\
\hline URBAN & $0.1634^{\star \star \star}$ & 0.0586 & $21.3402^{*}$ & -2.5055 \\
\hline Log likelihood & -4341 & -3237 & - & - \\
\hline Within group R2 & - & - & 0.20 & 0.22 \\
\hline
\end{tabular}

Note: ${ }^{* * *},{ }^{* *}$, and * indicate that the coefficient indicated is statistically significant at the 1,5 and 10 per cent levels, respectively. 
Table 6

Provision of services at Posyandu (child level model)

\begin{tabular}{|c|c|c|c|}
\hline & VITAMIN & ORALR & IMMUN \\
\hline \multicolumn{4}{|l|}{ Service provision to child } \\
\hline PUSKSTAFF & $0.24^{\star *}$ & $0.73^{\star \star \star}$ & $0.34^{\star \star \star}$ \\
\hline CHILDAGE & $0.21^{\star \star \star}$ & 0.008 & $-0.42^{\star \star \star}$ \\
\hline FRAC_VILFUND & $0.18^{\star}$ & -0.06 & 0.11 \\
\hline FRAC_POSREVIT & $0.19 * \star$ & -0.03 & -0.09 \\
\hline Gini of YPC & -0.17 & 0.33 & -0.08 \\
\hline \multicolumn{4}{|l|}{ Selection equation } \\
\hline YRSSCHOOL & 0.005 & 0.006 & $0.01^{*}$ \\
\hline AGE & -0.007 & -0.006 & -0.008 \\
\hline AGE squared & 0.00007 & 0.00005 & 0.00001 \\
\hline Gini of YPC & $0.48^{\star}$ & $0.53^{\star}$ & $0.61^{*}$ \\
\hline DMMARRIED & -0.10 & -0.09 & -0.08 \\
\hline KIDSO-5 & -0.02 & -0.03 & -0.02 \\
\hline URBAN & $0.15^{\star \star}$ & $0.17^{\star \star \star}$ & $0.22^{\star \star \star}$ \\
\hline DIVLANG & $-0.48^{\star \star \star}$ & $-0.48^{\star \star \star}$ & $-0.40^{\star \star \star}$ \\
\hline dmMJRLNG & 0.07 & 0.07 & 0.09 \\
\hline YPC (in millions of rupiah) & -0.03 & $-0.04^{*}$ & -0.01 \\
\hline CmYPC (in millions of rupiah) & $-0.14^{\star \star}$ & $-0.15^{\star * \star}$ & $-0.17^{\star \star \star}$ \\
\hline AVG_TINST & $-0.03^{\star \star}$ & $-0.03^{\star \star}$ & $-0.025^{\star \star}$ \\
\hline AVG_PUSKV & $-0.013^{\star *}$ & $-0.015^{\star *}$ & $-0.017^{\star \star *}$ \\
\hline AVG_FPLANV & 0.004 & 0.001 & 0.001 \\
\hline NUMBPOS & $0.03^{\star \star \star}$ & $0.03^{\star \star \star}$ & $0.027^{\star \star \star}$ \\
\hline NUMBPUSK & 0.01 & 0.01 & $0.014^{\star \star}$ \\
\hline CHILDMALE & 0.018 & 0.008 & 0.016 \\
\hline CHILDAGE & $-0.37^{\star \star \star}$ & $-0.36^{\star \star \star}$ & $-0.37^{\star \star \star}$ \\
\hline Rho $(u, v)$ & -0.36 & $0.41^{*}$ & $0.80^{\star \star \star}$ \\
\hline $\mathrm{N}$ & 1055 & 1055 & 1055 \\
\hline Log likelihood & -2484 & -2149 & -2435 \\
\hline
\end{tabular}

Note: ${ }^{* *},{ }^{*}$, and * indicate that the coefficient indicated is statistically significant at the 1,5 and 10 per cent levels, respectively. 
Figure $1 \mathrm{~A}$

Variation in supervisory visits to Posyandu from family planning clinic

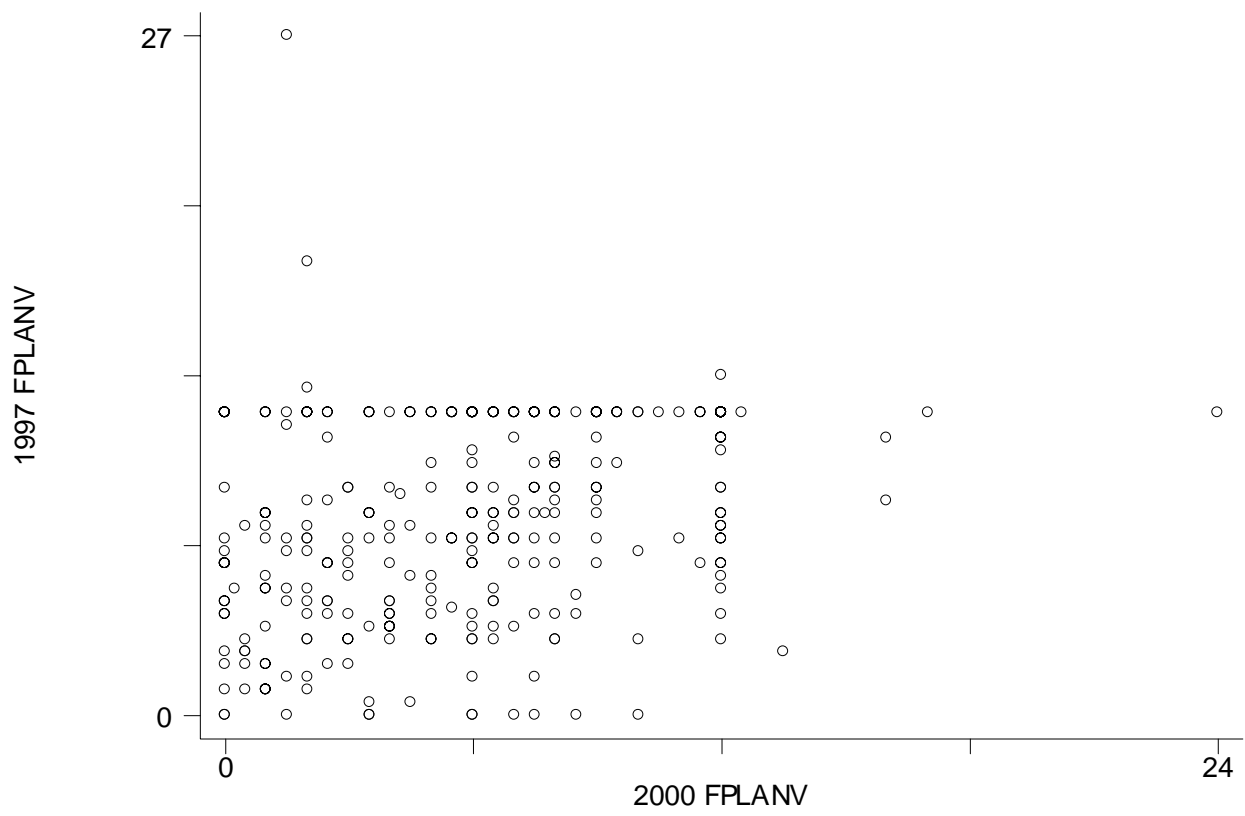

Figure 1B

Variation in total number of instruments in the Posyandu

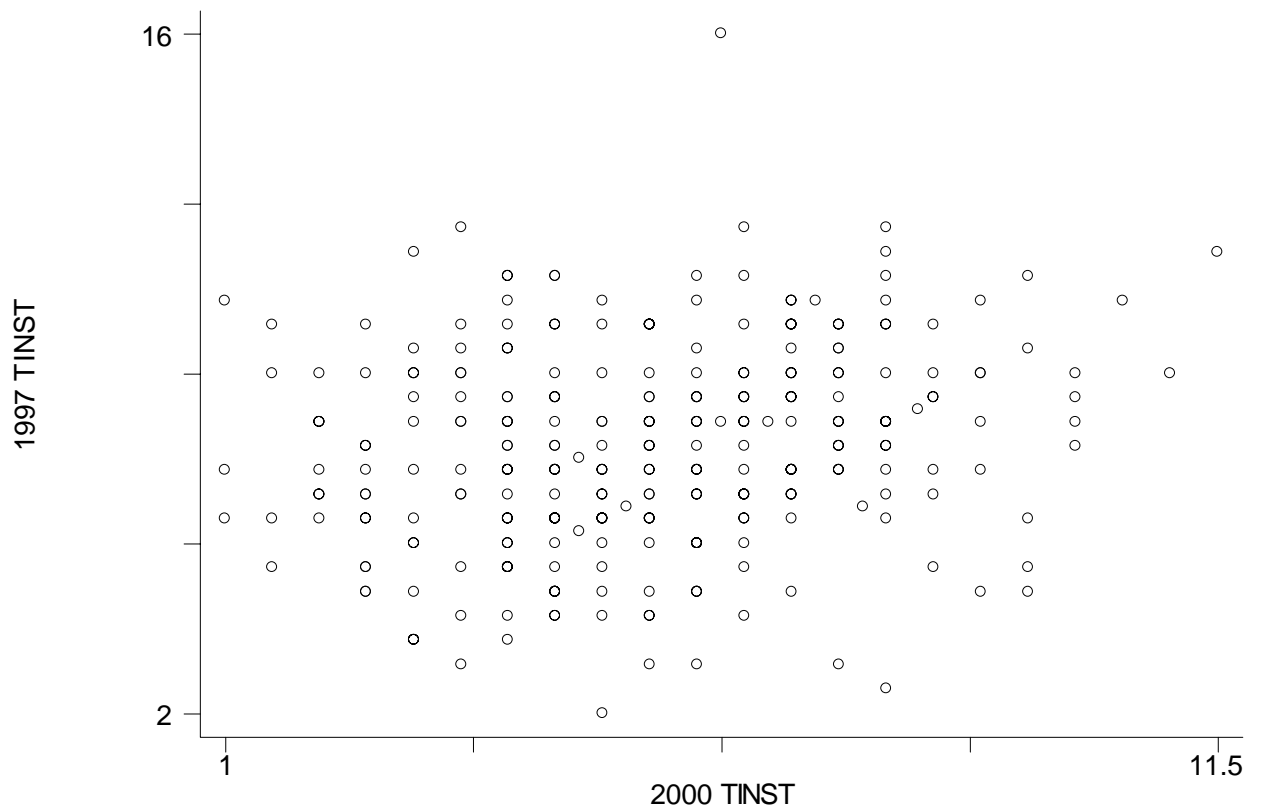


Figure 1C

Variation in the number of Posyandus

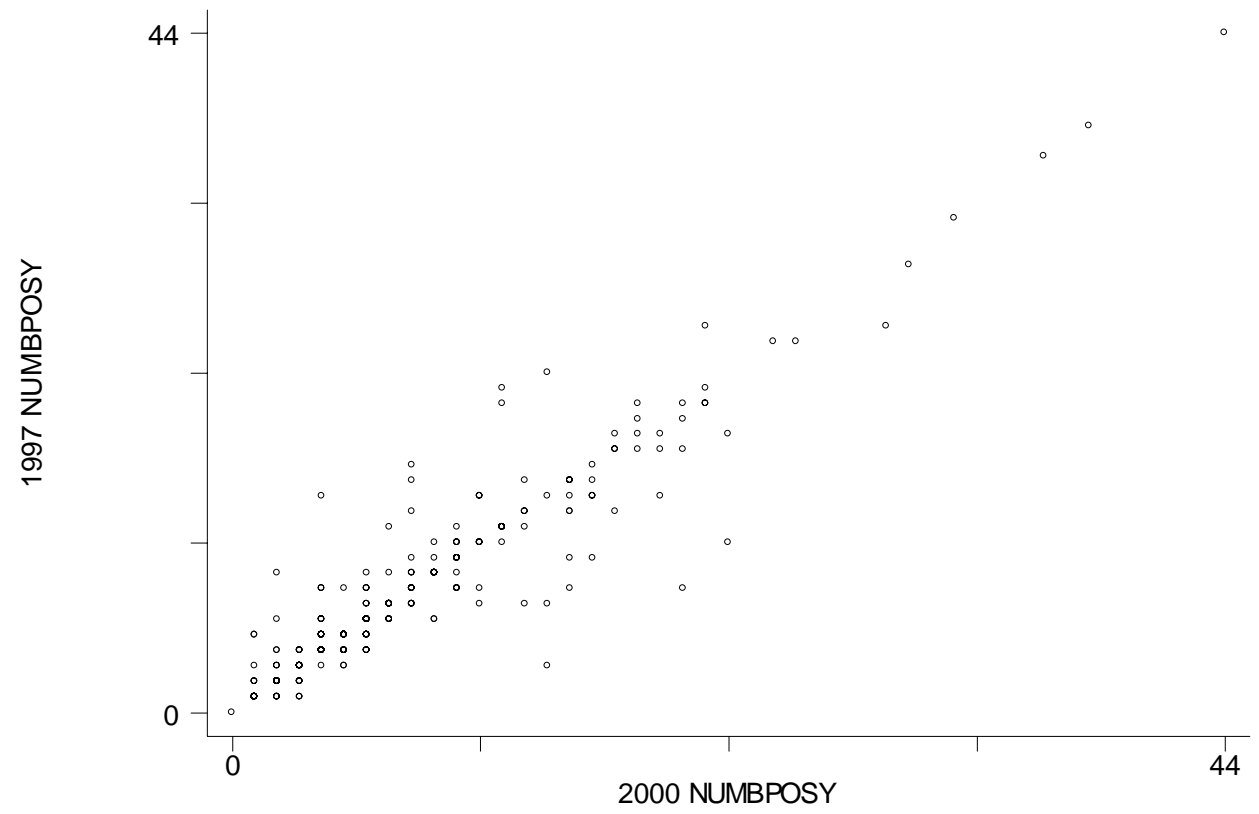

